\title{
TRANSLATION, ADAPTATION OR TRANSFERENCE: HAGIOTOPONYMS FOR FOREIGN DENOTATA IN THE HUNGARIAN LANGUAGE
}

\author{
ANDREa BöLCSKeI \\ Károli Gáspár University of the Reformed \\ Church in Hungary, Hungary
}

\begin{abstract}
Toponyms for foreign denotata that include a saint's name behave in a variety of ways in Hungarian texts. Certain place names are transferred from the source language without any change; other toponyms are adjusted to the features of the Hungarian language, or substituted with conventional Hungarian equivalents, which are often formed through direct translation. The paper examines whether factors such as the type of indicated denotatum, the motivation of the name form, the history of a saint's veneration, the cultural history of a place, the linguistic characteristics of the source name form, geographical location, historical and cultural contacts between the source language and the Hungarian speech communities, the medium through which Hungarians gained knowledge of the name, text types, conventions of language use in a given time period, etc. could have an influence on how the relevant toponyms have been adopted into the Hungarian language.

Keywords: hagiotoponyms, translation, language and cultural contacts, conventional equivalents, Hungarian.
\end{abstract}

\section{Introduction}

The paper first briefly discusses the translation operations that can theoretically be adopted to render proper names into foreign languages, based on claims from the relevant literature. Then it focuses on factors which may or may not have influenced the actual choice of translation operation when foreign hagiotoponyms were adopted into the Hungarian language in the past.

\section{Translation operations applicable to rendering proper names into foreign languages}

The translation operations applicable to rendering proper names into foreign languages are described in the relevant literature from either theoretical or practical points of view, by both onomasticians and translation theorists. In fact, the results coming from the different approaches often coincide.

2.1. In connection with the translation of proper names, the most general questions are (1) when to translate a proper name; and (2) how to achieve an appropriate 
"translation". Whenever the importance of a denotatum grows beyond the community to which it belongs and which, thus, first provided it with an identifying domestic name, there is a need to indicate the denotatum with a foreign name. As Katalin J. Soltész (1979: 118, my translation) said: "The translation of a proper name is in fact the designation of the same individual denotatum by using the means of a different language".

The relevant literature discusses the translation of proper names either from the perspective of onomastics (Soltész 1967, 1979: 118-123; Kálmán 1967; Hajdú 2003: 143-145; Várnai 2005: 77-84; Vermes 2005), or of translation theory (Klaudy 1997; Albin 2003, 2004; Castañeda-Hernández 2004; Särkkä 2007; Parianou 2007; Mizani 2008; Pusztai-Varga 2008). Experts from both fields agree that the methods adopted for translating proper names are dependent on certain linguistic features of the proper names themselves and also on how they are used in the language. Factors to be taken into consideration include the special meaning structure of the proper name (cf. Soltész 1967: 281, 1979: 118-119; Várnai 2005: 77-79; Vermes 2005: passim); the appellative transparency of the components of proper names, and consequently the general issues concerning the differentiation of proper names and common nouns (cf. Soltész 1967: 281-283, 1979: 118-119; Hajdú 2003: 143-145; Várnai 2005: 78, 84); the possible functions of proper names in texts (cf. Parianou 2007: 409-413); the status of proper names as cultural realia (cf. Klaudy 1997: 36-38; Várnai 2005: 83-84; Pusztai-Varga 2008: 89). Other, more complex aspects must also be considered: the conventions of language use, such as the time period when the foreign name was adopted into the target language, e.g. foreign personal names that entered the Hungarian language early display the Hungarian name order - the family name is followed by a Christian name: Tell Vilmos [Wilhelm Tell], Clark Ádám [Adam Clark], Verne Gyula [Jules Verne] (Soltész 1967; Várnai 2005: 84). Furthermore, certain extralinguistic (e.g. political) aspects can also play an important role, cf. names of the Soviet cultural community, as mentioned in Soltész 1967, were mostly borrowed by the Hungarian language through direct translation, e.g. Téli Palota [Зимний дворец, i.e. Zimniy Dvorets 'Winter Palace'], Vörös tér [Красная пмоощадь, i.e. Krasnaya Ploshchad 'Red Square'], Szellöcske [Ветерок, i.e. Veterok 'Light Breeze'] and Szenecske [Уголёк, i.e. Ugoljok 'Coal'] space dogs.

Experts also agree that in the case of proper names the concept of translation can be interpreted quite broadly. Operations applicable to rendering proper names into the target language range on a scale from complete lack of translation (i.e. transferring the unaltered name from the source to the target language) to strong alteration of the name form as a result of modification. However, the precise division of the scale into smaller units and the judgment on which linguistic features of proper names are essential in choosing the appropriate translation operation are influenced by the theoretical background used by the authors.

2.2. The translation of proper names is discussed in specialised literature from either a theoretical or practical point of view. Theoretical works themselves are based 
on two distinct platforms. Some experts consider that the type of indicated denotatum and formal aspects such as internal structure, complete or partial appellative transparency of the name form are essential when identifying the suitable translation operation (e.g. Soltész 1967, 1979: 118-123; Kálmán 1967; Hajdú 2003; Várnai 2005: 77-84; Särkkä 2007). Others believe that the function of a proper name in a text, its communicative value determined by the text type, matters much more when it comes to deciding on the appropriate translation operation (e.g. Vermes 2005; Parianou 2007).

Experts from both sides collect and categorize the theoretically possible methods of translation of proper names. Commonly acknowledged techniques include the unaltered transference of the source name form into the target language, sometimes involving unavoidable phonotactic adjustments (e.g. En. Tower Bridge $>$ Hun. Tower Bridge, It. Roma /'roma/ > Hun. Róma /'ro:ma/); the proper translation of the name form (Katalin J. Soltész [1967] differentiates between complete translation, e.g. En. Cape Town Hun. Fokváros, En. Chanel Islands Hun. Csatorna-szigetek, and partial translation, the latter affecting the appellative components and/or the morphemes of the name forms, e.g. En. North Dakota Hun. Észak-Dakota, Ger. Wörthersee Hun. Wörthi-tó, respectively). The substitution of the source name form with its conventional target language equivalent is also common (e.g. Ger. Wien $\sim$ En. Vienna $\sim$ Hun. Bécs, It. Venezia $\sim$ En. Venice $\sim$ Hun. Velence). In some cases, the Finnish researcher Heikki Särkkä (2007) finds it necessary to erase the name form (e.g. the fixed expression En. I have Hobson's choice Hun. egyáltalán nincs választásom, i.e. 'I have no choice at all') or to change the name form according to the target culture (e.g. the phrase En. to carry coals to Newcastle Hun. Dunába vizet hord, i.e. 'to carry water into the Danube'). These two methods are also mentioned by Albert Péter Vermes (2005) in his typology of translation techniques to render proper names into foreign languages, in the category of modification, i.e. substantially altering the name form. In Vermes's relevancetheory based approach, along with the two above-mentioned techniques, the category of modification also includes the explanation of the name form in the target language by adding a common noun (e.g. It. il Po $\sim$ En. the river Po $\sim$ Hun. Pó folyó).

The most significant difference of the two theoretical approaches can be seen in what they say about the behaviour of proper names in translation. Those who claim that the internal structure of the name forms is of primary importance in the adaptation process cannot identify exact rules which elicit the direct translation of proper names. As Judit Szilvia Várnai (2005: 82) emphasises, it is impossible to clearly delineate when to translate and when not to translate a proper name; the decision is based on cultural conventions and individual linguistic intuitions rather than on systematicity. The lack of rules provoking or preventing the translation of proper names is explained by Katalin J. Soltész (1967: 292) as the clash of two contrasting principles. The former is the requirement of the incommutability of proper names, guaranteeing their identifying quality. The latter is the requirement of intelligibility, achieved through adjustments to the target language. Since both principles cannot be valid at the same time, one must choose between them from time to time. Those who emphasise the importance of the 
function of proper names in texts, however, direct their attention to the essential role of proper names in successful interactions and highlight the systematic behaviour of proper names in translation, determined by the rules of communication (cf. Vermes 2005; Parianou 2007).

2.3. Several papers adopt a practical approach and present translation difficulties posed by certain types of proper names. Zoltán Rihmer (2008) discusses the possibilities of translation and adaptation explored in Latin certificates justifying academic degrees, and how contemporary Hungarian personal names are rendered into the target language. Advice on how to translate Hungarian geographical names (e.g. river names, settlement names, names for regions, country names) into English, illustrated with examples, are given by Károly Perényi (1981) and - with an emphasis on the need for geographical names standardisation - by Gábor Gercsák (2007, 2008, 2015). Current Hungarian trends in present-day map lettering are described by Gábor Mikesy (2008).

Enumerating exceptional name forms, the Mexican researcher Gilberto Castañeda-Hernández (2004) proves that while certain tendencies can be observed in the translation of geographical names, general rules could not be relied on. Thus, for instance, foreign language equivalents of the names for large old European towns are regularly produced by way of translation, while names for later established American cities are mostly transferred into the target language. In Spanish, names for European towns ending in -burg usually end with a final $-o$, while names of the same structure for American cities often remain unaltered. At the same time, feminine geographical names of Spanish origin ending in $-a$ frequently end in $-e$ in French to keep gender.

Solutions to typical problems in the translation of proper names (e.g. working out the target language equivalents of geographical names used in the plural, with a definite article, or being gender-specific in the source language; dealing with differences in the alphabets of the source and target languages when transferring proper names; possible influences on the translation of place-name changes triggered by historical or geopolitical factors; rendering geographical names of multinational areas into foreign languages) are suggested in two related articles by Verónica Albin $(2003,2004)$ from the United States. She proposes that translators should consult official lists of names and check target language texts to get acquainted with the conventional foreign language equivalents of the proper names concerned. Tamás Farkas examines how the perception of a linguistic expression as a common noun or as a proper name, as well as the presence or absence of the appellative meaning in the name form affect the choice of translation operations (2009). In another study (2007) he analyses some examples of the incorrect translation of proper names resulting from the adoption of inadequate translation operations.

2.4. To sum up the most important observations of the literature focusing on the possible methods of rendering proper names into foreign languages, it can be stated 
that translators should work out the foreign language name equivalents that are the most easily comprehensible to the target language audience, paying attention to the context of the target culture, to achieve communicative success (see also Albin 2003: 2, 2004: 6).

\section{Surveying hagiotoponyms for foreign denotata in the Hungarian language}

Based on selected examples of hagiotoponyms for foreign denotata in the Hungarian language collected from a reliable etymological place-name dictionary (FNESz), this section examines whether factors such as the type of indicated denotatum, the motivation of the name form, the history of a saint's veneration, the cultural history of a place, the linguistic characteristics of the source name form, geographical location, historical and cultural contacts between the source language and the Hungarian speech communities, the medium through which Hungarians gained knowledge of the name, text types, conventions of language use in a given time period, etc. could have an influence on how the relevant place names have been adopted into the Hungarian language.

3.1. Observed hagiotoponymic examples show that certain factors did, in fact, have an influence on the Hungarian forms of the relevant place names. However, even in these cases, tendencies, rather than certainties or rules can be discerned. The type of denotatum indicated, the time when the name was adopted, the medium through which Hungarians got to know the name were undoubtedly among influential factors.

With respect to the type of denotatum indicated, hagiotoponyms for large foreign geographical features were usually translated word for word into Hungarian, e.g. Ger. Sankt-Gotthard-Paß > Hun. Szent Gotthárd-hágó; Fr. Fleuve Saint-Laurent/En. Saint Lawrence River > Hun. Szent Lörinc-folyó (FNESz 2: 558, 562-3), while similar names for foreign settlements were regularly transferred without changes, even if special characters were included in the name forms: e.g. Fr. Saint-Tropez > Hun. Saint-Tropez; Port. São Paulo > Hun. São Paulo (FNESz 2: 435, 448). The same saint name may behave in different ways in place-name forms adopted into the Hungarian language, based on the difference in the type of geographical entities indicated: a telling example is Port. Santa Helena > Hun. Szent Ilona (island) and En. Saint Helens > Saint Helens (town) (FNESz 2: 559, 435). Still, there are exceptions. Large foreign geographical objects can be identified by transferred names in Hungarian, such as Sp. San Joaquin > Hun. San Joaquin, a river in California; Port. São Francisco > Hun. São Francisco, a river in Brazil (FNESz 2: 445, 448). These names could later be, although not necessarily, substituted by a properly translated form, e.g. Pol. Góry Świętokrzyskie > Hun. 1895: Swietokrzyska Gora (transference with an additional change in the order of the name components) > Hun. 1988: Szentkereszt-hegység (direct translation; FNESz 2: 561).

With regard to time, foreign hagiotoponyms adopted into the Hungarian language relatively early usually displayed some minor adjustments, many of which disappeared as time went by. The spelling of transferred name forms in the 18th-19th 
centuries differed from those of the original names, mostly in order to represent contemporary pronunciation according to Hungarian letter-to-sound rules. These differences, however, often ceased to exist by the 20th century, e.g. Ger. Sankt Pölten > Hun. 1792: S. Pölten > Hun. 1988: Sankt Pölten; Sp. Santa Fe > Hun. 1816: S. Fé> Hun. 1988: Santa Fe (FNESz 2: 446, 447). Spelling changes in the early transferred name forms may sometimes have been generated by the intention to disambiguate the meaning (i.e. the reference to the saint), e.g. Sp. Santiago de Compostela > Hun. 1757: Sant Jago $>$ Hun. 1816: S. Jago di Compostella > Hun. 1988: Santiago de Compostela; Sp./En. San Francisco > Hun. 1816: S. Francesco > Hun. 1988: San Francisco (FNESz 2: 447, 445).

In Hungarian, Latinised forms, e.g. It. San Marino > Hun. 1757: Marinumi Refpublica (> Hun. 1988: San Marino; FNESz 2: 446) and Greek interpretations of foreign hagiotoponyms, e.g. Sp. San Sebastián > Hun. 1757: Sebaftianopolis 'Sebastian's town' (> H. 1816: S. Sebastián > H. 1988: San Sebastián; FNESz 2: 447) were exceptional in the past and should be considered rare forms of modification. The Latin or Greek components added to the truncated foreign names definitely had an explanatory function for contemporary Hungarians. Not only words from classical languages, but also Hungarian common nouns were sometimes attached to the original or translated forms of the foreign hagiotoponyms, in the 19th century often through an additional suffix. The aim of these was to help in identifying the denotata: e.g. Ger. Sankt Wolfgang $>$ Hun. 1816: S. Volfgangi tó (adjustment in spelling, suffixation, additional common noun) (> Hun. 1988: Sankt Wolfgang; FNESz. 2: 446); Ger. Großer Sankt Bernhard and Kleiner Sankt Bernhard > Hun. 1884: Nagy-Sz.-Bernáti hágó and Kis Sz. Bernáti hágó (direct translation, suffixation, additional common noun) (> Hun. 2017: Nagy Szent Bernát-hágó and Kis Szent Bernát-hágó; FNESz. 2: 446, 555). As the last two name forms exemplify, some of these common nouns have remained parts of the name forms in the long run.

Early Hungarian hagiotoponyms for foreign denotata may also have evolved as a result of complex processes, such as partial translation with spelling modification, e.g. Ger. Sankt Gallen > Hun. 1694: Szent Gallon (> Hun. 1988: Sankt Gallen; FNESz 2: 446); the addition and omission of an explanatory term with a change in spelling, e.g. Sp. Santa Fe > Hun. 1757: Santa Fe de Paraguay > Hun. 1816: S. Fé (> Hun. 1988: Santa $\mathrm{Fe}$; FNESz 2: 447). The modern form is at times the result of the disappearance of the element 'saint' from the early Hungarian name form borrowed by way of modification, e.g. Sp. (El) Salvador > Hun. 1884: San Salvador > Hun. 1988: Salvador (FNESz 2: 442).

The transference of complete name forms, e.g. Sp. Santiago de Cuba > Hun. 1816: S. Jago de Cúba (with additional spelling changes) > Hun. 1988: Santiago de Cuba; Sp. Santiago de los Caballeros > Hun. Santiago de los Caballeros (FNESz 2: 447), as well as the ultimate transference of abbreviated name forms, e.g. Port. São Luís (do Maranhão) > Hun. 1816: S. Luis de Maragnan > Hun. 1988: São Luís (FNESz 2: 448) are equally represented among Hungarian hagiotoponyms for foreign denotata.

The earliest hagiotoponymic borrowings appeared in early Hungarian textbooks 
on geography, in the first non-translated Hungarian encyclopaedias, in literature focusing on disseminating scientific information. This medium is in favour of explicit explanation, which is well reflected in the early name forms clarifying the types of indicated denotata in single or double labelled possessive structures, e.g. Ger. SanktGotthard-Paß > Hun. 1694: Szent Gothard hegye (> Hun. 1893: Szt.-Gotthárd hágó > Hun. 1988: Szent Gotthárd-hágó; FNESz 558); Port. Santa Helena > Hun. 1757: Sz. Ilonának szigete (> Hun. 1988: Szent Ilona; FNESz 559); Fr. Fleuve Saint-Laurent/En. Saint Lawrence River > Hun. 1757: Sz. Lörintznek folyója (> Hun. Szent Lörinc-folyó; FNESz 2: 562-563).

3.2. However, the adoption of foreign hagiotoponyms into the Hungarian language was seemingly less influenced by the geographical location of the indicated denotatum, the motivation of the name form, the cultural history of the indicated place, the history of the saint's veneration, the linguistic characteristics of the source name form, the historical and cultural contacts between the source language and Hungarian speech communities.

Concerning the geographical location of the indicated denotatum, foreign hagiotoponyms for European geographical entities may have been adopted into the Hungarian language by way of transference, e.g. Fr. Saint-Étienne $>$ Hun. Saint-Étienne (FNESz 2: 435), It. Sanremo $\sim$ San Remo $>$ Hun. Sanremo $\sim$ San Remo (cf. also the unusual spelling as a single word; FNESz 2: 446). In some cases, these name forms were borrowed into Hungarian through direct translation, e.g. Ger. Kleiner Sankt Bernhard > Hun. Kis Szent Bernát-hágó (FNESz 2: 555). The same tendencies can also be observed when geographical entities of other continents are involved, e.g. En. Saint Paul > Hun. Saint Paul and Fr. Saint-Laurent/En. Saint Lawrence > Hun. Szent Lörincfolyó in North America (FNESz 2: 435, 562).

Direct or indirect motivation of the name form also seems to have been insignificant when it came to choosing the adequate translation operation. Foreign names motivated by direct connections, assumed or real, between the eponymous saint and the indicated place were mostly transferred into Hungarian. For example, Fr. SaintDenis > Hun. Saint-Denis (Saint Denis was supposed to have been buried there; FNESz 2: 435); Ger. Sankt Gallen > Hun. Sankt Gallen (Saint Gall was believed to have established a monastery in the town; FNESz 2: 446); Ger. Sankt Wolfgang > Hun. Sankt Wolfgang (Saint Wolfgang of Regensburg was said to have lived in a monastery nearby; FNESz 2: 446). Foreign names motivated by possessing a relic, for instance, may also have been transferred, e.g. Sp. Santiago de Compostela > Hun. Santiago de Compostela (its cathedral houses the alleged relics of Saint James the Greater; FNESz 2: 447), or translated as Hungarian borrowings: e.g. Pol. Góry Świętokrzyskie > Hun. Szentkereszthegység (the Benedictine abbey found there possesses a relic of the Holy Cross; FNESz 2: 561).

Foreign hagiotoponyms displaying indirect motivation also show the same duality. Place names evolved from the name of the patron saint of the local church, chapel 
or monastery could be adopted into the Hungarian language as transferred names, e.g. Fr. Saint-Quentin > Hun. Saint-Quentin (after a church dedicated to Quentin of Amiens; FNESz 2: 435), or as translated names: e.g. Ger. Sankt-Gotthard-Paß > Hun. Szent Gotthárd-hágó (after a 12th-century chapel dedicated to Gotthard of Hildesheim; FNESz 2: 558). Toponyms developed from the name of a nearby physical geographic or habitational feature may also have been transferred, e.g. En. San Antonio > Hun. San Antonio (Texas, the town, was named after its river; FNESz 2: 444), or translated into Hungarian: e.g. Rom. Brațul Sfintul Gheorghe > Hun. Szent György-Duna (named after the settlement Sfintu Gheorghe at the mouth of this branch of the river Danube; FNESz 2: 558).

Events in the cultural history of the place expressed in foreign hagiotoponyms do not seem to have consistently affected the ways names were borrowed into Hungarian. Foreign names identifying the saint or the sacred object whose celebration was due on the day when the place was discovered turned either into transferred names, e.g. Sp. Santa Cruz de Tenerife > Hun. Santa Cruz de Tenerife (in 1520 the first Portugal ship arrived at the local bay on 14th September, the day of the feast of the Cross; FNESz 2: 447), or into translated names in Hungarian, e.g. Port./Sp. Santa Helena > Hun. Szent Ilona (in 1502 the island was discovered on 22th May, Saint Helen's feast day; FNESz 2: 559). Foreign hagiotoponyms of this type were transferred into Hungarian whether the name giver was known, e.g. En. San Diego > Hun. San Diego (California, named by Sebastián de Viscaíno; FNESz 2: 444), or unknown: e.g. Sp./En. San Francisco > Hun. San Francisco (California, named by Spanish people; FNESz 2: 445). In rarely occurring cases, the hagiotoponymic form is misleading: e.g. Port. São Luís (do Maranhão) > Hun. 1988: São Luis (with actual reference to the French king Luis XIII; FNESz 448).

Differences in the saints' veneration in distinct parts of the world had no real effect on translation operations either. Foreign hagiotoponyms referring to saints that were well known or less known in Hungary were equally transferred, e.g. En. Saint Paul $>$ Hun. Saint Paul (Minnesota, reference to Paul the Apostle; FNESz 435), Fr. SaintCyr $\left(-l^{\prime}\right.$ École) > Hun. Saint-Cyr (reference to Saint Quiricus [Cyriacus]; FNESz 435), respectively. Foreign names referring to saints respected deeply in Hungary were sometimes transferred, e.g. Sp. San Juan > Hun. San Juan (reference to John the Baptist; FNESz 446), and were translated on other occasions, e.g. Fr. Saint-Laurent/En. Saint Lawrence > Hun. Szent Lörinc-folyó (reference to Saint Lawrence; FNESz 2: 562).

Foreign hagiotoponyms from different languages were transferred into Hungarian, e.g. Fr. Saint-Germain(-en-Laye) > Hun. Saint-Germain; Sp. San José > Hun. San José; Ger. Sankt Wolfgang > Hun. Sankt Wolfgang; En. Saint Helens > Hun. Saint Helens; Port. São Paulo > Hun. São Paulo (FNESz 2: 435, 445, 446, 435, 448); and hagiotoponyms from the same foreign language were transferred or translated, e.g. Ger. Sankt Moritz $>$ Hun. Sankt Moritz; Ger. Sankt-Gotthard-Paß > Hun. Szent Gotthárd-hágó (FNESz 2: 446, 558), respectively. When borrowed by Hungarians, complicated name forms were occasionally shortened, e.g. Sp. Santiago de Nueva Estremadura ('Saint James of New Estremadura') > Hun. Santiago (FNESz 2: 447). In other cases, they were left 
unaltered, e.g. Sp. Santiago de los Caballeros > Hun. Santiago de los Caballeros ('Saint James of the knights', first inhabited by knights of the Order of Saint James in the 15th century; FNESz 2: 447); Sp. San Luis Potosí > Hun. San Luis Potosí (named after the silver-mining Bolivian city of Potosí; FNESz 2: 446).

Historical and cultural contacts between the source language and Hungarian speech communities were sometimes obviously present in the past. Despite these relations, foreign hagiotoponyms were borrowed into Hungarian either as transferred names, e.g. Ger. Sankt Gallen > Hun. Sankt Gallen (Hungarian raiders were reported to have attacked its abbey in the 10th century; FNESz 2: 446), or as translated names, e.g. Pol. Góry Świętokrzyskie > Hun. Szentkereszt-hegység (the relic of the Holy Cross in its Benedictine abbey was supposedly donated by Saint Emeric of Hungary; FNESz 2: 561).

\section{Conclusion}

Translation operations used when adopting foreign hagiotoponyms into the Hungarian language include transference, (complete or partial) direct translation, and spelling or structural modifications (i.e. ways of adaptation). A few factors such as the type of the indicated denotatum, the conventions of language use in a given time period, the medium through which Hungarians got to know the name tend to have influenced the choice of the adopted translation operations to a certain extent. However, these are only tendencies, not strict rules. Other factors such as geographical location, the motivation of the name form, the cultural history of the place, the history of the saint's veneration, the linguistic characteristics of the source name form, the historical and cultural contacts between the source language and Hungarian speech communities seem to have been less influential in translation strategies.

\section{References}

Albin, V. 2003. What's in a Name: Juliet's Question Revisited. Translation Journal 7 (4). http:// translationjournal.net/journal/26names.htm (accessed August 15, 2017).

Albin, V. 2004. Does Juliet's Rose, by Any Other Name, Smell as Sweet? Translation Journal 8 (1). http://translationjournal.net/journal/27names.htm (accessed August 15, 2017).

Castañeda-Hernández, G. 2004. Navigating through Treacherous Waters: The Translation of Geographical Names. Translation Journal 8 (2). http://translationjournal.net/journal/28names.htm (accessed August 15, 2017).

Farkas, T. 2007. A tulajdonnevek fordíthatóságáról és napjaink fordítási hibáiról, közszók és tulajdonnevek példáján [On the translation of proper names and on today's mistranslations, considering proper names as well as common nouns]. Névtani Értesitő 29: 167-188.

Farkas, T. 2009. A tulajdonnevek fordításának alapkérdéseiről. Diadal vagy Viktória, Eugén vagy Jenő? [On basic questions of translating proper names. Diadal or Viktória, Eugén or Jenő?] Forditástudomány 11 (2): 22-35.

FNESz = Kiss, L. 1988. Földrajzi nevek etimológiai szótára 1-2 [Etymological dictionary of geographical names 1-2]. Fourth edition. Budapest: Akadémiai Kiadó.

Gercsák, G. 2007. Magyar tájnevek angol fordítása [Translation of Hungarian geographical 
names into English]. In Ezerarcú lexicon, Á. Fóris and Sz. Tóth (eds.), 100-110. Szombathely: BDF.

Gercsák, G. 2008. Magyar és angol országnevek a fordításban [Hungarian and English country names in translation]. Fordítástudomány 10 (1): 71-78.

Gercsák, G. 2015. Magyar tónevek angol fordítása [English translations of Hungarian lake names]. Névtani Értesitö 37: 77-81.

Hajdú, M. 2003. Általános és magyar névtan [General and Hungarian onomastics]. Budapest: Orsis Kiadó.

Kálmán, B. 1967. A nevek világa [The world of names. A study in Hungarian onomatology]. Budapest: Gondolat.

Klaudy, K. 1997. A forditás elmélete és gyakorlata [The theory and practice of translation]. Budapest: Scholastica.

Mikesy, G. 2008. Új utak és trendek a térképi névírásban [New trends in using geographical names on maps]. In Név és valóság. A VI. Magyar Névtudományi Konferencia elöadásai. Balatonszárszó, 2007. június 22-24, A. Bölcskei and I.N. Császi (eds.), 204-211. Budapest: Károli Gáspár Református Egyetem Magyar Nyelvtudományi Tanszéke.

Mizani, S. 2008. Proper Names and Translation. Translation Journal 12 (3). http://translationjournal.net/journal/45proper.htm (accessed August 15, 2017).

Parianou, A. 2007. Translating Proper Names: A Functionalist Approach. Names 55 (4): 407-416.

Perényi, K. 1981. Hogyan fordítsuk a magyar helyneveket? [How to translate Hungarian place names?] Magyar Nyelvőr 105 (3): 377-378.

Pusztai-Varga, I. 2008. A forrás- és célkultúra viszonyának hatása a fordítói megoldásokra (Kulturálisan kötött kifejezések átültetése versfordítások esetén) [How source and target culture affects translation strategies (Translating culturally bound expressions in poems)]. Folia Uralica Debreceniensia 15: 83-111.

Rihmer, Z. 2008. Fordítás vagy adaptáció? A modern latin személynévhasználat problémái [Translation or adaptation? Problems in the contemporary use of Latin personal names]. In Név és valóság. A VI. Magyar Névtudományi Konferencia előadásai. Balatonszárszó, 2007. június 22-24, A. Bölcskei and I.N. Császi (eds.), 450-460. Budapest: Károli Gáspár Református Egyetem Magyar Nyelvtudományi Tanszéke.

Särkkä, H. 2007. Translation of Proper Names in Non-fiction Texts. Translation Journal 11 (1). http://translationjournal.net/journal/39proper.htm (accessed August 15, 2017).

Soltész, K.J. 1967. A tulajdonnevek lefordíthatósága [The translatability of proper names]. Magyar Nyelvör 91 (3): 280-292.

Soltész, K.J. 1979. A tulajdonnév funkciója és jelentése [The function and meaning of proper names]. Budapest: Akadémiai Kiadó.

Várnai, J. Sz. 2005. Bárhogy nevezzük... A tulajdonnév a nyelvben és a nyelvészetben [Proper names in language and in linguistics. Possible approaches to proper names]. Budapest: Tinta Könyvkiadó.

Vermes, A.P. 2005. Proper Names in Translation: A Relevance-Theoretic Analysis. Debrecen: Kossuth Egyetemi Kiadó. 